Marco Goldoni/Christopher McCorkindale (Eds.)

\title{
Hannah Arendt and the Law
}

Volume 4 in the series Law and Practical Reason

Oxford, Portland, Hart Publishing, 2012, hbk 382 p., £ 55,00, ISBN: 978-1-84946-143-6

"Hannah Arendt and the Law" is a title that arouses curiosity, exactly because there is no coherent theory of law developed by Hannah Arendt. However, the volume manages in an admirable way to bring together various aspect of Arendt's work to show how many insights can be gained from Arendt for our thinking about law. Her ideas and suggestions especially contain a considerable potential with a view to the debates on the universality of international law and the integration of the Global South into a truly universal global order. Particularly, Arendt's concept of the "right to have rights" implying the idea of a right to membership and her consideration of international criminal law are worth mentioning in this respect. The first section of the volume treats Arendt's general concept of law, followed by a second section that concentrates on the issue of constitutionalism and political institutions within the state. The third section is dedicated to Hannah Arendt's thinking about the international law, while the fourth and last part deals with the famous term of the "right to have rights".

The way in which the term of the "right to have rights" is taken up and discussed in academia ${ }^{1}$ could be considered a prime example of what Hannah Arendt called the unpredictability of human action. ${ }^{2}$ She may herself never have imagined the expression of the "right to have rights" to become such a focal point of discussion when she framed it 1951 in "The Origins of Totalitarianism". But although the conceptions built on the notion might go far beyond Arendt's own ideas, we owe her every credit for this inspiring initiation. The topic is dealt with by several authors in the current volume: Charles Barbour, James Bohman and Samantha Besson contribute their perspectives in the last section, while Seyla Benhabib, Hauke Brunkhorst and Jan Klabbers pick up the theme in other contexts. They all advance distinct readings of the "right to have rights" and enter into some interesting dialogues. The different interpretations are guided and delimitated by three questions: What is the meaning of the "right to have rights"? How can the status of such right be qualified? And to which grade and in which manner can we speak of an actual or possible realization of that right?

For Samantha Besson, two groups of universal rights concur in the "right to have rights": Rights to membership and the rights as a member of a community. ${ }^{3}$ The former grant the access to membership in a political community and can therefore be legally guaranteed only from outside a political community. The latter assure the creation and securing of human rights

1 And not only in academia: The Concurring Opinion of Judge Pinto de Albuquerque in the landmark decision of the ECHR in Hirsi Jamaa et al. v. Italy, begins with a reference to the "right to have rights" and its possible recognition; ECHR Grand Chamber, Case Hirsi Jamaa and other v. Italy, 23 February 2012, Application no. 27765/09.

2 Hannah Arendt, The Human Condition, Chicago 1958, p. 191.

3 Samantha Besson, The Right to Have Rights: From Human Rights to Citizens' Rights and Back, in: Goldoni/McCorkindale (eds.), Hannah Arendt and the Law, p. 348. 
by States, and must therefore be legally realized from inside a political community. Based on a conception of rights as intermediaries between interests and duties, Besson states that human rights have an inherently legal dimension and can only exist as "moral rights qua legal rights". ${ }^{4}$ Therefore, the right to have rights can not be seized within the strict opposition between moral and legal rights. Besson objects Seyla Benhabib in her reading of the "right to have rights" as being composed of the moral imperative (the first "right") and the legal rights that are to be established.

Seyla Benhabib developed that reading of the term in earlier works. ${ }^{5}$ She therein explained the different meanings of the two "rights" within the term as the first one being a moral claim to membership and the second representing legal rights that are to be guaranteed. In her present contribution, Benhabib does not so much reiterate her argument on the right to have rights but rather contextualizes the work of Arendt by drawing some parallels between her vita and that of Raphael Lemkin. However, Benhabib picks up the theme of the right to have rights when she describes Arendt's ambivalent attitude towards the nation state. ${ }^{6}$ It is this ambivalence towards the system of the nation state in Arendt's thought that leads Benhabib to qualify the right to have rights as a certain passage between the sphere of the moral and the sphere of the legal.

Charles Barbour reads the right to have rights as the possibility of action and politics outside a particular legal order. ${ }^{7}$ He emphasizes that the chapter "The perplexities of the Rights of Man", in which Arendt introduces the term, must not be read in isolation and thus integrates his reading of the term within a consideration of Arendt's theory of action. Starting from an understanding of "right" as the capacity to act, Barbour develops an interpretation of the right to have rights as a person's capacity to act after and despite being excluded from political membership. Barbour is also skeptical about Benhabib's qualification of the first "right" as a moral imperative as this could turn the notion into some passive experience, and thereby remove it from the sphere of political action.

In his contribution on power and the rule of law in Arendt's thought, Hauke Brunkhorst picks up the expression of the right to have rights and presents a very far reaching interpretation thereof. He considers Arendt's idea of a revolutionary constitution to include the principle of democratic inclusion and thus to be a blueprint for conceptualizing global democracy. Based on that analysis, Brunkhorst reads the right to have rights as the "emerging right of any human being to have national and transnational civic and democratic rights". 8

Jan Klabbers touches upon the right to have rights in his contribution on Arendt's thought in relation to the phenomenon of global governance. He therein describes the recent evolution

4 Ibid., p. 345.

5 Seyla Benhabib, Transformations of citizenship, 2001, p. 16 et seq.; Seyla Benhabib, The Rights of Others, 2004, p. 56 et seq.

6 Seyla Benhabib, International Law and Human Plurality in the Shadow of Totalitarianism: Hannah Arendt and Raphael Lemkin, in: Goldoni/McCorkindale (eds.), Hannah Arendt and the Law, p. 202.

7 Charles Barbour, Between Politics and Law: Hannah Arendt and the Subject of Rights, ibid., p. 315.

8 Hauke Brunkhorst, Power and the Rule of Law in Arendt's Thought, ibid., p. 227. 
of international law and concludes with a very instructive imagination of what Arendt possibly had to say about global governance today. Klabbers reads the right to have rights to state that membership in a political community forms the precondition for the fundamental rights of a person to be protected. ${ }^{9} \mathrm{He}$ assesses that especially rights to political participation such as the right to vote and the right to be elected are denied vis-à-vis persons outside political communities.

In his contribution, James Bohman deals with the question how the legal status of an individual and the protection of his fundamental rights correlate, and aims to explore the philosophical differences between Arendt and Kant in this respect. Bohman postulates a cosmopolitan form of republicanism, in which the legal status of a person stands independently from the membership in a particular political community. In his opinion, prospects for a realization of the right to have rights can be seen in the cosmopolitan constitutions of particular political communities. Such a cosmopolitan constitution grants equal rights to all persons and protects them from domination - independently from their status as citizens or non-citizens. With regard to the content, Bohman distinguishes two ways Arendt parsed the right to have rights, once as the right to belong to a particular political community and once as the right to belong to humanity as such. ${ }^{10} \mathrm{He}$ himself favors the second reading that overcomes a statecentered conception of the global order. According to such interpretation the right to have rights contains a moral claim to citizenship or at least to the recognition as a legal person.

Bohman's reference to the two readings that Arendt herself offers for the right to have rights leads us to consider her redaction of the relevant chapter in "The Origins of Totalitarianism". In a first English version of the book published in 1951, the right to have rights is put alongside with the right to belong to some kind of organized community. ${ }^{11}$ Whereas the two terms are not equated, the right to have rights is regularly interpreted that way. Arendt herself translated and redacted the book to a German version which was published in 1955 and which is in some respects more detailed. A second English version was then published in 1958, in which inter alia the chapter on "The Perplexities of the Rights of Man" was revised and enlarged. The German as well as the second English version contain an additional passage, in which Arendt equates the right to have rights with the right to belong to humanity as such. ${ }^{12}$ In the preface to the second English edition, Arendt emphasizes that all changes and

9 Jan Klabbers, Hannah Arendt and the Languages of Global Governance, ibid., p. 243.

10 James Bohman, Citizens and Persons: Legal Status and Human Rights, ibid, p. 333.

11 Hannah Arendt, The Origins of Totalitarianism, 1951, p. 294: "We became aware of the existence of a right to have rights (and that means to live in a framework where one is judged by one's actions and opinions) and a right to belong to some kind of organized community, [...]". The same wording is also contained in both the German and the second English version.

12 Hannah Arendt, The Origins of Totalitarianism, $2^{\text {nd }}$ edition 1958, p. 298: “[...], would mean in this context that the right to have rights, or the right of every individual to belong to humanity, should be guaranteed by humanity itself.". 
amendments should not be read to alter the meaning of the relevant passages. ${ }^{13}$ Taking that statement seriously, we must assume that Arendt favored from the beginning an interpretation of the rights to have rights as the right to belong to humanity as such. However, to strictly separate those two ways to parse the notion would mean to inappropriately simplify the issue. The tension between the right to belong to a particular political community and the right to belong to humanity can rather be taken as a reflection of Arendt's ambivalent attitude towards the nation state. ${ }^{14}$

Besides this major theme discussed so far, the book contains various further contributions. The first section of the book deals with Arendt's conception of law at large. Two books by Arendt are of special relevance in this respect: "The Human condition" published in 1958, in which she develops her theory of political action, and "On Revolution" published in 1963, in which she compares the French and the American Revolution, thereby assessing the paradox of beginning and the issue of revolution in general. Arendt's idea that such revolutionary beginning may take place without violence is explored in the contribution by Michael $A$. Wilkinson. ${ }^{15}$ The article by Keith Breen examines the way Arendt generally rejects any dependence of law from command or coercion. ${ }^{16}$ Both authors address the concepts of "nomos" and "lex" in Arendt's thought. The law in the sense of "nomos" is pre-political, reflecting the Greek notion that law is constitutive for political action as it demarcates the space. Contrary, "lex" stands for law in the sense of mutual agreements between persons and thereby reflects the Roman conception that the making of law is inherently political. While Wilkinson describes Arendt's conception of law as a turn from "nomos" to "lex", Breen rather understands it as a consolidation of both concepts. Johan van der Walt shows in his article in how far Arendt's philosophy is based on insights and presumptions of phenomenology. ${ }^{17}$ Vivian Liska finally compares Arendt's conception of law to the one advanced by Giorgio Agamben, who considers himself an intellectual heir of Arendt. ${ }^{18}$

The second part of the book treats Arendt's consideration of constitutionalism and political institutions. "On Revolution" is her most relevant book in this respect. In a first contribution, Emilios Christodoulidis and Andrew Schaap reconstruct the distinction of the social and the political made by Arendt. ${ }^{19}$ In their opinion, the strict separation of the two fields yield prob-

13 Cf. Hannah Arendt, The Origins of Totalitarianism, $2^{\text {nd }}$ edition 1958, Preface to the Second Enlarged Edition, p. xi.

14 As it is phrased by Seyla Benhabib, International Law and Human Plurality in the Shadow of Totalitarianism: Hannah Arendt and Raphael Lemkin, in: Goldoni/McCorkindale (eds.), Hannah Arendt and the Law, p. 202.

15 Michael A. Wilkinson, Between Freedom and Law: Hannah Arendt on the Promise of Modern Revolution and the Burden of 'the Tradition', ibid., p. 59.

16 Keith Breen, Law beyond Command? An Evaluation of Arendt's Understanding of Law, ibid., p. 24 et seq.

17 Johan van der Walt, Law and the Space of Appearance in Arendt's Thought, ibid., p. 63 et seq.

18 Vivian Liska, A Lawless Legacy: Hannah Arendt and Giorgio Agamben, ibid., p. 89 et seq.

19 Emilios Christodoulidis/Andrew Schaap, Arendt's Constitutional Question, ibid., p. 101 et seq. 
lematic consequences. They particularly criticize Arendt's treatment of the social question and its isolation from the political sphere. The following contribution by Marco Goldoni and Chris McCorkindale treats the role of the Supreme Court in Arendt's thought. It examines her concept of authority and describes her nuanced understanding of the important yet limited position of judges within the constitution. ${ }^{20}$ Further contributions by William Smith and by Kari Palonen explore Arendt's account of civil disobedience and of the political deficiencies in parliamentarism.

The third part of the volume is dedicated to Arendt's thought in relation with international law. The contributions by Seyla Benhabib, Hauke Brunkhorst and Jan Klabbers have already been mentioned. Florian Hoffmann raises the question whether the international law is in crisis and discusses issues of fragmentation and re-politicization. ${ }^{21}$ Patricia Owens, Leora Bilsky and Lawrence Douglas contribute on the topic of international criminal law. They reproduce Arendt's thought in this respect from "Origins of Totalitarianism" to "Eichmann in Jerusalem", exploring its development and change. While Owens especially deals with the issue of bureaucracy that Arendt described as characteristic for imperialism, ${ }^{22}$ Bilsky focuses on the question whether it is possible to judge the crimes of Holocaust and, more generally, what international criminal law can accomplish. ${ }^{23}$ Douglas draws an analogy between the trial of Eichmann in Jerusalem and the recent trial of Demjanjuk in Munich. ${ }^{24}$ He collates the questions of the current case with Arendt's findings on the Eichmann trial, concluding that Demjanjuk as a person was accessory, what illustrates well the problematic nature of judgment.

I shall take this as a cue to come to a concluding judgment about the book. Does it fill a major gap in the ever-increasing secondary literature on Hannah Arendt's political thought as it claims in the blurb? The volume definitely approaches the multi-faceted oeuvre of Arendt from a new angle and shades some light on questions related with the theory of law. It comprises many worthwhile contributions and benefits from the diverse academic backgrounds of the authors. One special treat are the comparisons and correlations drawn between Arendt and other scholars, both contemporaries and successors. In summary, the volume not only provides for an entertaining reading but also enables us to learn about much more than Arendt's legal thought.

Dana Schmalz, Heidelberg

20 Marco Goldoni/Chris McCorkindale, The Role of the Supreme Court in Arendt's Political Constitution, ibid., p. 117.

21 Florian Hoffmann, Facing the Abyss: International Law before the Political, ibid., p.173 et seq.

22 Patricia Owens, 'How Dangerous it Can Be to Be Innocent': War and the Law in the Thought of Hannah Arendt, ibid. p. 268.

23 Leora Bilsky, Hannah Arendt's Judgement of Bureaucracy, ibid., p. 271 et seq.

24 Lawrence Douglas, Arendt in Jerusalem, Demjanjuk in Munich, ibid., p. 291 et seq. 